Journal of Applied Veterinary Sciences, 6 (3): 48 -53 (July 2021).

ISSN: Online: 2090-3308, Print: 1687-4072

Journal homepage : https://javs.journals.ekb.eg

\title{
Virologic Detection and Molecular Characterization of Canine Parvovirus-2 in Dogs
}

\author{
Morcos I.Yanni *; Ebtsam,A.Abouelyazeed; Nadia Maher Hanna; Hala K. Abdelmegeed \\ and Omnia M. Khattab \\ Virology Department, Animal Health Research Institute (Dokki), Agriculture Research Centre (ARC), \\ Giza, Egypt. \\ *Corresponding Author, Morcos I.Yanni; E-Mail: morcosyanni70@gmail.com
}

\begin{abstract}
This study aimed to search the extent of spread of various canine parvovirus variants in Egypt from year 2019 to year 2020 and the ability of the present used vaccines in the protection. In this study, twenty fecal samples were collected from diarrheic puppies. These samples were tested by rapid CPV Ag test kits for the detection of CPV-2 Ag. Ten samples were found positive for CPV2 by rapid Ag test kit (VDRG CPV Ag rapid kit).Positive samples were propagated on Vero cell culture for 8 passages, CPE appears in the form of cell rounding and detachment within 5 days. A conventional polymerase chain reaction test was performed on tissue culture isolates. Partial sequencing of five randomly selected positive samples revealed the presence of 2 CPV2C and 3 CPV2B.CPV2B represents the highest level of the variant serotype of CPV circulating in Egypt through records of egyptian isolated cases at the gene bank. One of the isolate has $100 \%$ identity with a CPV2B of cat origin. Our isolates CPVS1 and CPVS4 have 100\% nucleotide identity with each other and with CPV cairo1-19 and CPV cairo3-19 belonging to CPV2C , this variant is also widespread all over the country. Continuous accurate molecular and epidemiological studies are needed to follow-up the new mutation of the virus genome which may result in vaccination failure(The majority of the used vaccines in Egypt are of CPV2 origin not of variant origin). The use of CPV2b based vaccine gave better protection than cpv2 based vaccine(Wide range protection against CPV2 variants). The obvious spread and emergence of newly introduced CPV variants at different Egyptian governorates as cited at previous study necessitates updated molecular based epidemiological studies of field isolates continuously to follow up the efficacy of the concurrent used vaccines.
\end{abstract}

Keywords: Canine parvovirus, Dog, Egypt, PCR, Sequencing.
Original Article:

DOI:https://dx.doi.org/10.21608/javs.20

$\underline{21.78123 .1082}$

Received :29 May, 2021.

Accepted :28 June, 2021.

Published in July, 2021.

This is an open access article under the term of the Creative Commons Attribution 4.0 (CC BY) International License. To view a copy of this license, visit:

http://creativecommons.org/licenses/by/4.0/

J. Appl. Vet. Sci., 6(3 ): 48 -53.

\section{INTRODUCTION}

Canine parvovirus-2 is a fatal virus for dogs. Emergence and spread of new variants worldwide forced us to study the extent of their existence at the last years in Egypt and the effectiveness of the current used vaccine in protection. Canine parvovirus (CPV) is a non-enveloped, linear, single-stranded DNA virus that belongs to the family Parvoviridae, genus Protoparvovirus. The CPV2 genome is $5.2 \mathrm{~kb}$ long containing two open reading frames (ORFs) (Cotmore et al., 2014). The non-structural ORF encodes two nonstructural proteins (NS1and NS2), the structural ORF encodes the capsid proteins VP1 and VP2 ( Reed et al., 1988).
The original CPV strain designated as type-2 (CPV2) was reported in the 1970s and soon after that in the 1980s, two antigenic variants termed CPV types 2a (CPV2a) and 2b (CPV2b) were reported (Parrish $\boldsymbol{e t}$ al.,1985 and 1991). The antigenic variants of CPV2 are classified based on the amino acid present at position 426 of theVP2 capsid protein, asparagine (Asn) for CVP2a, aspartic acid (Asp) for CPV2b, and glutamic acid(Glu) for CPV2c (Decaro and Buonavoglia., 2012).

In Egypt, the disease was first recorded in 1982 and recently was recorded by Al-Hosary (2018) and Soliman et al., (2018). They recorded that CPV-2a and CPV-2b were the circulating genotypes in Egypt. 
Infection with CPV-2c is slightly different from the common infection with CPV-2a and CPV-2b. It showed severe gray watery diarrhea, vomiting, dehydration, and anorexia (Wafaa et al., 2019 ; Amani and Khodier, 2020). Bloody diarrhea is not common in CPV-2c infection. (Oliveira et al., 2018). So accurate detection is necessary to avoid misdiagnosis with other causes of diarrhea.

So, this study aimed to search the extent of spread of various canine parvovirus variants in Egypt at 2019 and 2020 and the ability of the present used vaccines in protection.

\section{MATERIAL AND METHODS}

\section{Samples:}

Small-animal veterinarians participated in sample collection from 2019-2020. Twenty Fecal samples from diarrheic unvaccinated cases suspected for CPV were collected with detailed clinical history and stored properly at $-20{ }^{\circ} \mathrm{C}$ until used. Ten positive fecal materials detected by rapid antigen test kits (VDRG CPV Ag rapid kit) were prepared as 10\% suspensions (w/v) in $0,15 \mathrm{M} \mathrm{pH} 7.2$ of phosphate buffer saline.. Each sample was passed through a cellulose ester filter (Millipore 65) pore size $200 \mathrm{~nm}$ and inoculated on freshly seeded Vero cells. (Appel $\boldsymbol{e t}$ al., 1979). Confirmation of positive fecal samples and positive trials of virus isolation on Vero cell isolates were performed by conventional polymerase chain reaction using primers cited by Sanjay Kapil et al., (2007).

\section{Rapid Ag test kit (VDRG CPV Ag rapid test-Cat} No. PC-CPV-11): CPV-Ag on suspected fecal swabs was detected by rapid Ag test kits (VDRG CPV Ag rapid kit).

3.Trials for virus isolation on Vero cells: The samples were inoculated on Vero cell suspension for 8 passages. The tissue culture was left for 4-5 days till complete cytopathic effect $\mathrm{CPE}$ (rounding, detachment of cells) The method of seeding accords with that of (Sanjay Kapil et al., 2007) who isolated CPV on cell culture of Vero with Grandell -Rees feline kidney cells (Grfk) after 1h incubation).

\section{Conventional polymerase chain reaction (PCR):}

As shown in Table 1, Primers according to (Sanjay Kapil, 2007) to detect any kind of cpv2 denaturation at $94 / 30 \mathrm{sec}$-annealing at 47/45 secextension at $72 / 1 \mathrm{~min}$.
Table 1: Primers used to detect any kind of CPV2

\section{CANINE PARVOVIRUS GENOME}

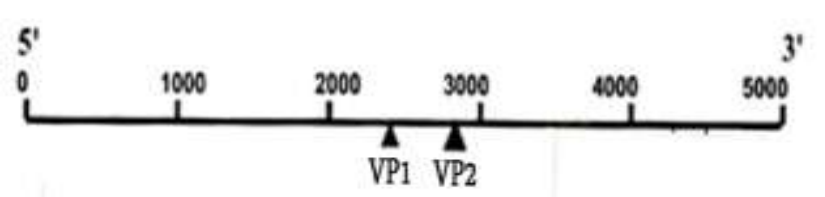

NUCLEOTIDE SEQUENCE IN THE CPV GENOME

\begin{tabular}{|c|c|c|c|c|}
\hline Primet prebe & Sequedoe $5^{\prime}$ to $3^{\prime}$ & Sense & Pation & Ampliosen size \\
\hline $555-60 n^{3}$ & CAGGAAGATATCCAGAAGGA & + & $4003-4022$ & 583 \\
\hline $555-\mathrm{en}^{3}$ & GGTGCTAGTTGATATGIAATAAACA & - & $4561-4565$ & bp \\
\hline
\end{tabular}

\section{DNA Sequencing and Phylogenetic Analysis:}

The analyzed sequences (583 bp of VP2 from position 4003 to 4585 ) of five samples were submitted on the Gen-Bank with accession numbers of (MT811047, MT811048, MT811049, MT811050, and MT811051). The phylogenetic tree was done using maximum likelihood and neighbor-joining in MEGA6.

\section{RESULTS}

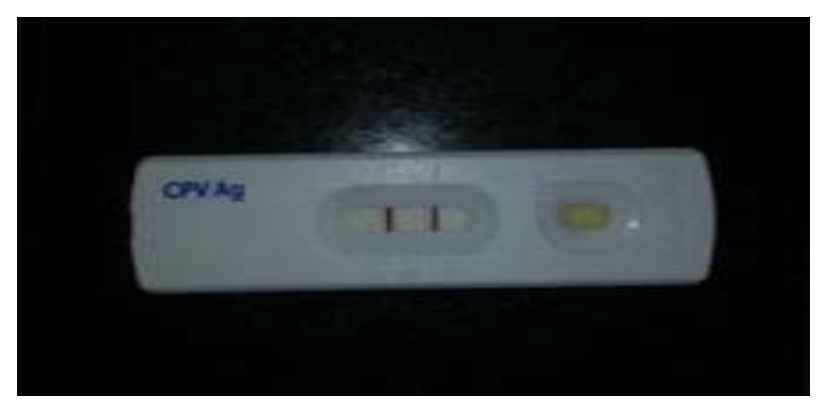

Fig. 1: Positive canine parvovirus fecal swab (found at 10 swabs out of 20) using a rapid antigen test kit

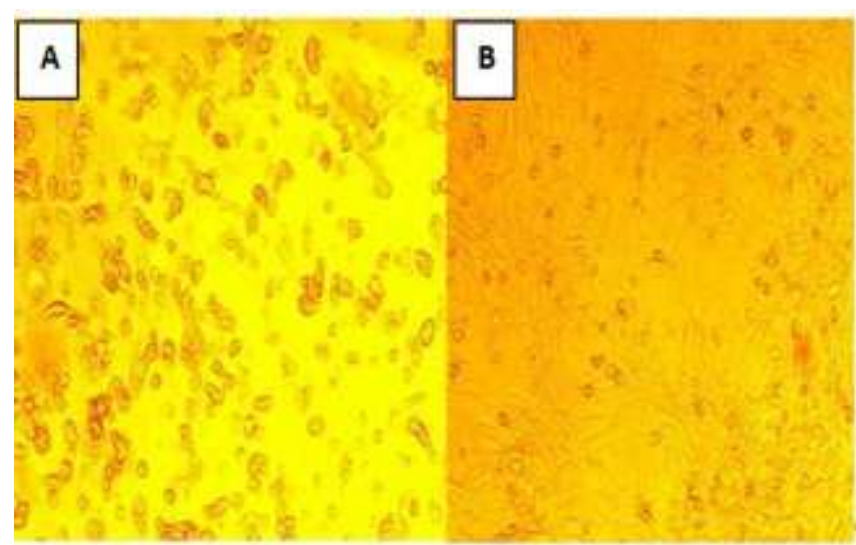

Fig. 2: Canine parvovirus infected Vero cells showing rounding, detachment of cells (A) and negative control cells (B). 
Virologic Detection and Molecular Characterization of ......

Table2: Data of different isolates from gene bank used at the phylogenetic analysis:

\begin{tabular}{|c|c|c|c|c|c|c|}
\hline No & Access No & Host & Serotypes & Year & Country & Abbreviation \\
\hline 1 & Mt811047 & $\operatorname{dog}$ & $2 \mathrm{c}$ & 2019 & Egypt(cairo19) & Cpvs1 \\
\hline 2 & Mtb11048 & $\operatorname{dog}$ & $2 b$ & 2019 & Egypt(cairo19) & Cpvs2 \\
\hline 3 & Mt811049 & $\operatorname{dog}$ & $2 b$ & 2020 & Egypt(giza20) & Cpvs3 \\
\hline 4 & Mt811050 & dog & $2 c$ & 2020 & Egypt(giza20 & Cps4) \\
\hline 5 & Mt811051 & $\operatorname{dog}$ & $2 b$ & 2020 & Egypt(giza20) & Cpvs5 \\
\hline 6 & Ab054221 & cat & $2 b$ & & japan & \\
\hline 7 & $\begin{array}{l}\text { Mk614452 } \\
\text { ali22 }\end{array}$ & $\operatorname{dog}$ & $2 b$ & 2017 & egypt & Cpv egy17 \\
\hline 8 & $\begin{array}{l}\text { Mk614453 } \\
\text { ali44 }\end{array}$ & $\operatorname{dog}$ & $2 b$ & 2018 & egypt & Cpvegy118 \\
\hline 9 & $\begin{array}{l}\text { MK614454 } \\
\text { ali66 }\end{array}$ & $\operatorname{dog}$ & $2 b$ & 2018 & Egypt & Cpvegy218 \\
\hline 10 & M19296 & - & 2 & - & - & $\begin{array}{c}\text { Norden } \\
\text { strain }\end{array}$ \\
\hline 11 & EU914139 & & 2 & & - & Pfizer strain \\
\hline 12 & MK6422722c & $\operatorname{dog}$ & $2 c$ & 2019 & Egypt & $\begin{array}{c}\text { Egypt } \\
\text { CPV Cairo } \\
1-19\end{array}$ \\
\hline 13 & MK6422742c & $\operatorname{dog}$ & $2 \mathrm{c}$ & 2019 & Egypt & $\begin{array}{c}\text { Egypt } \\
\text { CPV Cairo } \\
\text { 3-19 }\end{array}$ \\
\hline 14 & $\begin{array}{l}\text { FJ222823 2b } \\
29 / 97\end{array}$ & - & $2 b$ & - & - & $\begin{array}{c}\text { Vac } \\
\text { strain29/97 }\end{array}$ \\
\hline 15 & $\begin{array}{l}\text { FJ222822 2b } \\
\text { SAH }\end{array}$ & - & $2 b$ & - & - & $\begin{array}{l}\text { Fort-dodge } \\
\text { vac }\end{array}$ \\
\hline 16 & M74852 133 & - & $2 b$ & 1990 & USA & Strain133 \\
\hline 17 & M74849 39 & - & $2 b$ & 1984 & USA & Strain39 \\
\hline 18 & KR869678 2a & - & $2 a$ & 2014 & china & China3 \\
\hline 19 & KP715699 & - & $2 b$ & & Thailand & Thailand3 \\
\hline 20 & KU866402 & - & $2 a$ & 2011 & India & India2011 \\
\hline 21 & KU866393 & - & $2 a$ & 2014 & India & India2014 \\
\hline 22 & KR869671 2a & - & $2 a$ & 2014 & china & China2 \\
\hline 23 & KR002800 2a & - & $2 a$ & 2014 & china & Chinal \\
\hline 24 & KP715694 & - & $2 b$ & - & Thailand & Thailand1 \\
\hline 25 & KP715689 & - & $2 b$ & - & Thailand & Thailand2 \\
\hline 26 & FJ005196 2c & - & $2 c$ & - & Germany & refCpv2c \\
\hline 27 & FJ011098 & - & 2 & - & - & Intervet \\
\hline 28 & FJ011097 & - & 2 & - & - & Merial \\
\hline
\end{tabular}

CPVS1 and CPVS4 have 100\% nucleotide identity with each other and with CPV cairo1-19 and CPV cairo3-19 belonging to CPV2C. CPVS5 has a 100\% nucleotide identity with a CPV2b isolated from a cat (Yasuhiro et al., 2000) .CPVS3 and cpvs2 have 100\% identity with the Egyptian isolates CPVegy17, CPVegy118, and CPVegy218 that belong to CPV2b. 


\section{Morcos I.Yanni et al..........}

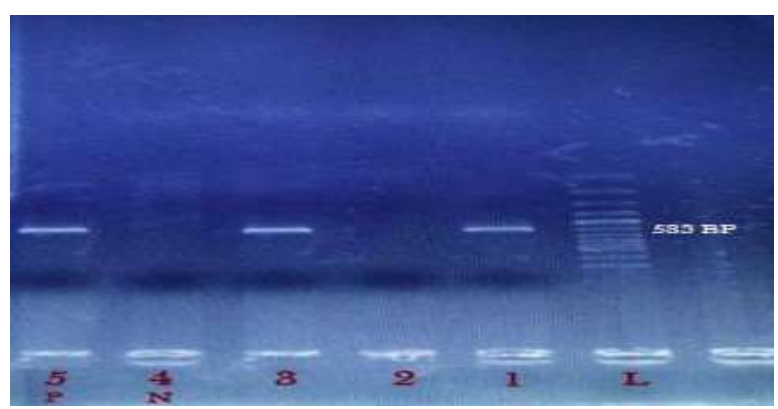

Fig. 3: PCR product of 583bp lanes 1, 3 and 5 are positive samples and positive control respectively while lanes 2 and 4 are the negative controls

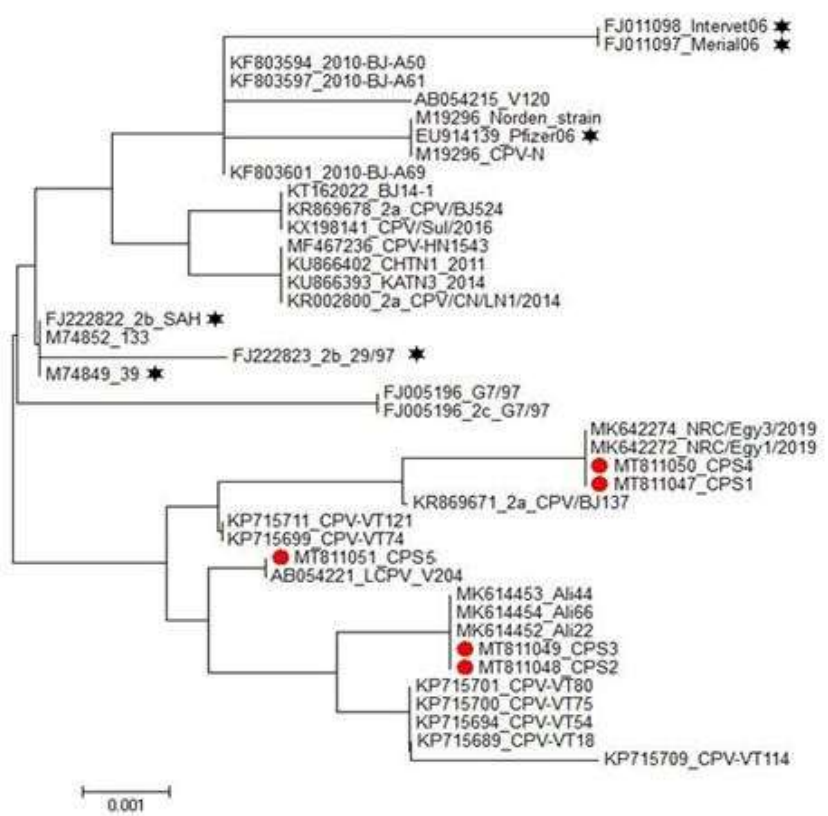

Fig. 4: Phylogenetic analysis based on partial sequence of VP2 for the studied isolates against different sequences of canine parvovirus in the gene bank
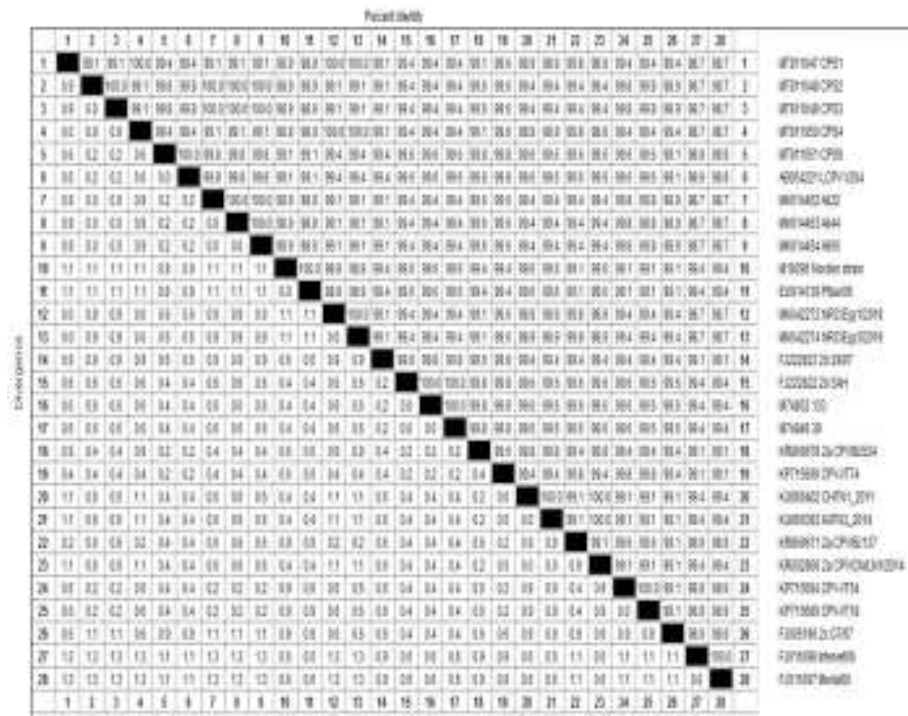

Fig. 5: The percent of nucleotide identity and divergence among the studied isolates different sequences of canine parvovirus used at the phylogenetic analysis.

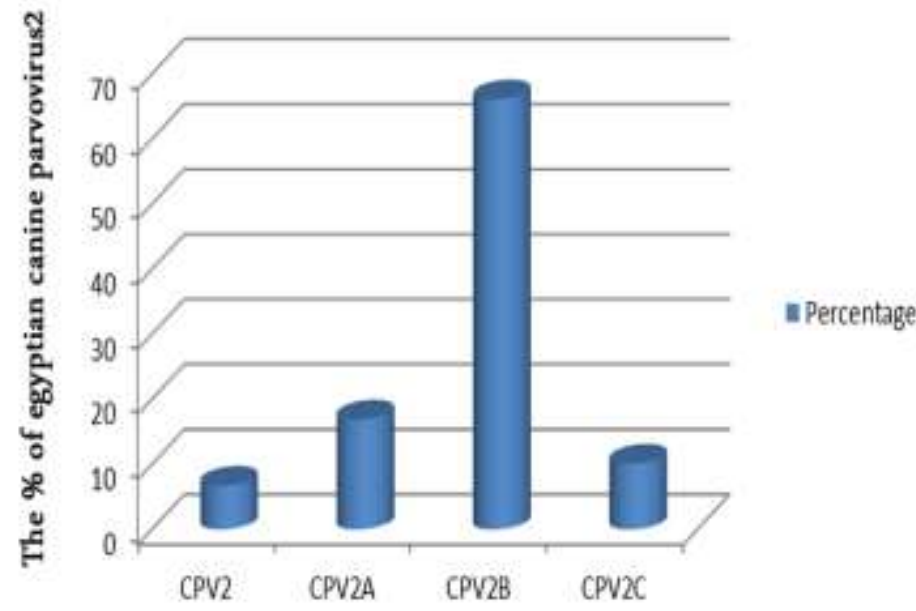

The egyptian canine parvovirus2 serotypes recorded at gene bank

Fig. 6: The percentage of Egyptian CPV serotypes recorded at gene bank at the period from 2011 till 2020.

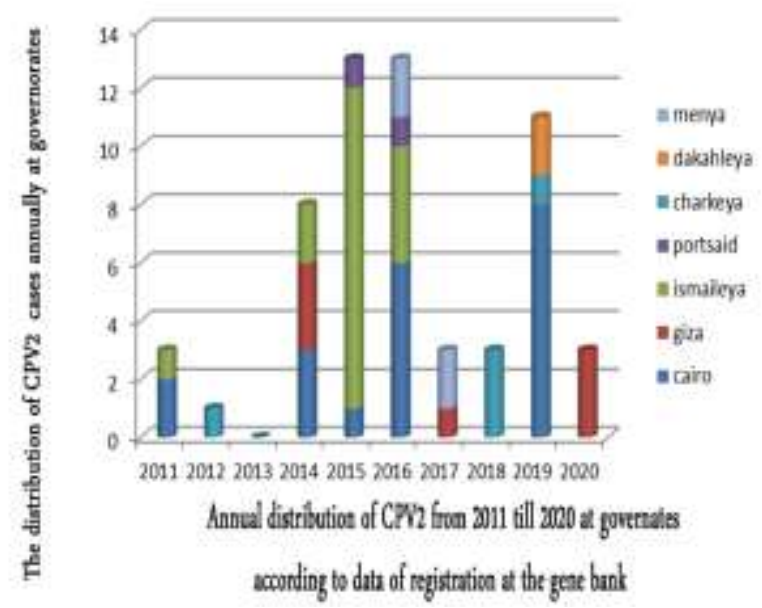

Fig. 7: The distribution of CPV cases annually per governorate at the period from 2011 till 2020 according to data of registration at the gene bank

\section{DISCUSSION}

The three variants of CPV-2 (CPV-2a, CPV$2 b$, and CPV-2c) are circulating in Egypt with a rapid spread between the different Egyptian governorates. Amino acid substitutions continuously occur in VP2 of CPV-2. (Wafaa El-Neshwy et al., 2019)

CPV S3 and CPVS2 have 100\% identity with the Egyptian isolates CPV egy17, CPV egy18 and CPV egy218 that belong to CPV2b.(of $100 \%$ nucleotide identity circulating in Egypt among different Egyptian governorates at 2017,2018,2019 and 2020) (Table 2).

On the other hand, our isolate CPVS5 has $100 \%$ identity with a CPV2b of cat origin. This means that our isolate may also have the ability to infect the cat population that acts consequently as a source for infection. CPV2b represent the highest level of the variant serotype of CPV circulating in 
Egypt (from data recorded at gene bank at the period from 2011 till 2020) (Table 3 and Fig. 6).

As there is a risk of reverse to virulence (Decaro et al., 2007), the rate of nucleotide substitution (high genetic mutation rate)at $\mathrm{CPV}$ is closer to that of RNA viruses than to that of doublestranded DNA viruses ( Laura A Shackelton et al., 2005, Decaro and Buonavoglia, 2012), the evidence of recombination of CPV and FPLV in nature (Takahisa Ohshima and Masami Mochizuki, 2009) and the wider host range for variants CPV2a and $b$ gained the ability to replicate in cats...(Yasuhiro et al., 2002).

Our isolates CPVS1 and CPVS4 have 100\% nucleotide identity with each other and with CPV cairo1-19 and CPV cairo3-19 belonging to CPV2C. $\mathrm{CPV} 2 \mathrm{C}$ recorded cases are the variant. CPV-2c was first recorded at the Giza governorate in 2014(access number at gene bank (KM212945) and Dakahlia governorate access number at gene bank (MN218613). This means that this variant is spreading in the country.

Continuous accurate molecular and epidemiological studies are needed to follow-up the new mutation of the virus genome which may result in vaccination failure. The continuous spread of new variants of the virus makes it necessary to take care of the vaccines used against the diseases especially the available vaccines in Egypt are believed to be protective against all types of CPV-2. Most of currently used canine parvovirus vaccines are CPV-2 based vaccines.

The use of CPV2b based vaccine gave better protection than cpv2 based vaccine. Dogs vaccinated at 6 weeks of age with the CPV2b fraction at minimum immunizing dose when administered subcutaneously, were protected from virulent CPV2C challenge in presence of maternally derived antibodies to CPV (Sherry Glover et al., 2012).

\section{CONCLUSION}

The obvious spread and emergence of newly introduced CPV variants at different Egyptian governorates necessitates updated molecular based epidemiological studies of field isolates continuously to follow up the efficacy of the concurrent used vaccines. Challenge test is needed to evaluate commercial vaccine with Egyptian strains.

\section{ACKNOWLEDGEMENT}

We thank Department of Virology, Animal Health Research Institute, Egypt for providing facilities to carry out this research.

\section{Statement of conflict of interests}

All authors declare there is no conflict of interest.

\section{REFERENCES}

AL-HOSARY, A.A.T., 2018. Detection and Molecular Characterization of Parvovirus Serotypes in Egypt. J. Adv.Vet. Res., 79-83 Vol.8 (4). ISSN:2090-2677/20906269.

AMANI ALI SALEH AND MOHAMED HASSAN KHODIER., 2020. Preliminary Studies On The Virus Causing Outbreak Of Duckling Short Beak And Dwarfism Syndrome (SBDS) In Egypt. Journal of Applied Veterinary Sciences, 5(4): 55-60. https://dx.doi.org/10.21608/javs.2020.118004.

APPEL, MJ., SCOTT, FW. AND CARMICHEL, LE., 1979. Isolation and immunization studies of a canine parvo like a virus from dogs with hemorrhagic $\begin{array}{llll}\text { enteritis.Vet. Rec 105:156-159. DOI: } & \end{array}$ 10.1136/vr.105.8.156.

COTMORE SF., AGBANDJE-MCKENNA M., CHIORINI JA, MUKHA D V., PINTEL DJ, QIU J, J., SODERLUND,VENERMO, M., TATTERSAll, P., TIJSSEN, P., GATHERER, D., AND DAVISON, A. J., 2014. The family parvoviridae. Arch Virol. 159:1239-47. DOI:10.1007/s00705-013-1914-1.

DECARO, N. AND BUONAVOGLIA, C., 2012. Canine parvovirus-a review of epidemiological and diagnostic aspects, with emphasis on type 2c. Vet Microbiol. 155:1-12. DOI:10.1016/ j.vetmic.2011.09.007

DECARO N, MARTELLA V, ELIA G, DESARIO C, CAMPOLO M, LORUSSO E, COLAIANNI ML, LORUSSO A. AND BUONAVOGLIA C., 2007. Tissue distribution of the antigenic variants of canine parvovirus type 2 in dogs. Vet Microbiol. 121(1-2):39-44. Epub 2006 Nov 21. DOI:10.1016/j.vetmic.2006.11.005

LAURA, A., SHACKELTON, COLIN R., PARRISH, UWE., TRUYEN AND EDWARD C. HOLMES, 2005. High rate of viral evolution associated with the emergence of carnivore parvovirusProc Natl Acad Sci. 102(2): 379-384. DOI:10.1073/PNAS.0406765102

OLIVEIRA PSBD., CARGNELUTTI JF, MASUDA EK, FIGHERA RA, KOMMERS GD, SILVA MCD., WEIBLEN R. AND FLORES EF ., 2018. Epidemiological, clinical, and pathological features of canine parvovirus $2 \mathrm{c}$ infection in dogs from southern Brazil. Pesquisa Vet. Brasil. 38: 113-118. DOI.og/10.1590/1678-5150-PVB-5122

PARRISH C R, O'CONNELL P H, EVERMANN J F AND CARMICHAEL, L E., 1985. Natural variation of canine parvovirus. Science. Nov 29;230(4729):1046-8. doi: 10.1126/science.4059921.

PARRISH C R, AQUADRO C F , STRASSHEIM M L , EVERMANN J F, SGRO J Y. AND MOHAMMED H O., 1991. Rapid antigenic-type replacement and DNA sequence evolution of canine $\begin{array}{lllll}\text { parvovirus. J Virol. } 65 & \text { (12):6544-52. doi: }\end{array}$ 10.1128/JVI.65.12.6544-6552. 
REED, AP, JONES, E V. AND MILLER, TJ., 1988. Nucleotide sequence and genome organization of canine parvovirus. J Virol. 62:266-76. DOI:10.1128/JVI.266-276.1988.

SANJAY KAPIL, EMILY COOPER, CATHY LAMM, BRANDY MURRAY, GRANT REZABEK, LARRY JOHSTON, GREGORY CAMPBELL AND BILL JOHNSON., 2007. Canine parvovirus type $2 \mathrm{c}$ and $2 \mathrm{~b}$ circulating in North American dogs in 2006 and 2007.J. Clinical Microbiology 4044-4047 DOI:10.1128/JCM.0130007

SHERRY GIOVER, BS; GRAIG ANDERSON, BS; MIKE PIONTKOWSKI, DVM. AND TERRY NG., 2012. Canine parvovirus (CPV)Type 2B vaccine protects puppies with maternal antibodies to $\mathrm{CPV}$ when challenged with virulent $\mathrm{CPV}-2 \mathrm{c}$ virus. Intern J Appl.Res Vet. Med. 10(3) 217-224 https://www.researchgate.net/publication/286031618_

SOLIMAN RM, BAKER NM, NASR MY. AND KHODEIR MH., 2018. Clinical, virological, and molecular characterization of canine parvovirus in dogs. Euro. J. Pharmaceut. Med. Res.5: 525-535 . DOI| http://dx.doi.org/10.17582/journal.rjvp/2019/7.4.74.82

TAKAHISA OHSHIMA AND MASAMI MOCHIZUKI., 2009. Evidence for Recombination Between Feline Panleukopenia Virus and Canine Parvovirus Type 2.Journal of Veterinary Medical Science , 71 (4) 403-408. DOI: 10.1292/jvms.71.403

WAFAA M. EI-NESHWY, HEBA EI-ZAHAR, ABDELKEREEM M. MORSI, TAREK SHETY., 2019. Molecular and Phylogenetic Analysis of Canine Parvovirus Variants(2A-2B-2C) in Egypt. Research Journal of Veterinary Practitioners 7(4): 74-82. http://dx.doi.org/10.17582/journal.rjvp/2019/7.3.74.82

YASUHIRO IKEDA, MASAMI MOCHIZUKI, RISAKO NAITO, KAZUYA NAKAMURA, TAKAYUKI MIYAZAWA, TAKESHI MIKAMI, and EIJI.AND TAKAHASHI, 2000 .The predominance of Canine Parvovirus (CPV) in Unvaccinated Cat Populations and the Emergence of New Antigenic Types of CPVs in Cats. Virology 278: 13-19 . https://doi.org/10.1006/viro.2000.0653

YASUHIRO IKEDA; NAKAMURA, K; MUJAZAIVA; TAKAAHASHI E. MOCHIZUKIM., 2002. Feline host range of canine parvovirus: recent emergence of new antigenic types in cats.Emergency Infectious Dis. 8(4)341346.DOI:10.3201/eid0804.010228.
How to cite this article:

Morcos I.Yanni; Ebtsam,A. Abouelyazeed; Nadia Maher Hanna; Hala K. Abdelmegeed and Omnia M. Khattab, 2021. Virologic Detection and Molecular Characterization of Canine Parvovirus-2 in Dogs. Journal of Applied Veterinary Sciences, 6 (3): $48-53$.

DOI: https://dx.doi.org/10.21608/javs.2021.78123.1082 